\title{
Condromatosis sinovial de la articulación temporomandibular
}

\section{Synovial chondromatosis of the temporomandibular joint}

\author{
P. Quirós Alvarez', F. García Marín', M. Burgueño García², R. Vázquez Carnero
}

Resumen: La afectación de la ATM por una condromatosis sinovial es un hecho muy poco frecuente. Trastorno metaplásico del tejido sinovial, suele producir cuerpos libres, condromas, intraarticulares. Tiene una clínica variable y muy inespecífica. Las pruebas diagnósticas de elección son la RM y la artroscopia. La retirada de cuerpos libres y sinovectomía parcial suele ser terapéutica. Ocasionalmente puede destruir la base del cráneo y extenderse intracranealmente. Se han descrito casos de malignización secundaria. Es necesario el seguimiento a largo plazo del paciente. Presentamos un caso con osteolisis incipiente de la fosa cerebral media.

Palabras clave: Condromatosis sinovial; Extensión intracraneal; Tratamiento; Seguimiento.

Recibido: 12.07.2005

Aceptado: 23.01.2006
Abstract: Synovial chondromatosis very rarely affects the TMJ. It is a metaplastic disorder of the synovial tissue that usually produces intra-articular loose bodies, or chondromas. It has variable clinical features and the symptoms are unspecific. Examination by means of magnetic resonance imaging and arthroscopic observation are the diagnostic techniques of choice. Treatment consists in the removal the loose bodies and partial synovectomy. Occasionally the skull has been destroyed and the middle cranial fossa invaded. There are cases of malignant transformation to chondrosarcoma. A long-term follow up is necessary. We describe a case with incipient intracranial extension.

Key words: Synovial chondromatosis; Intracranial extension; Treatment; Follow-up.

1 Cirujano Oral y Maxilofacial. Práctica Privada. Madrid.

2 Cirujano Oral y Maxilofacial. Servicio de Cirugía Oral y Maxilofacial. Hospital

Universitario La Paz. Madrid.

3 Patólogo. Laboratorio HistioCitoMed. Madrid, España.

Correspondencia:

Dr. Pedro Quiros Alvarez

Avda. Betanzos, $603^{\circ} \mathrm{D}$

28034 Madrid, España.

Email: pquirss@hormail.com 


\section{Introducción}

La afectación de la articulación temporomandibular (ATM) por una condromatosis sinovial (CS) es muy poco frecuente. Se desarrolla a partir de la condrometaplasia de la subíntima sinovial, formándose múltiples nódulos cartilaginosos que son liberados al espacio articular. En la mayoría de los casos el proceso queda limitado a dicho espacio, pero en ocasiones distiende la cápsula articular, protruyendo hacia la región parotídea o base del cráneo. Se han descrito cuadros de comportamiento agresivo con erosión del hueso temporal e invasión intracraneal.

\section{Caso clínico}

Mujer de 44 años que acude por presentar limitación de la apertura oral progresiva y tumoración preauricular izquierda, de años de evolución. Sin antecedentes de interés.

En la exploración se aprecia una tumoración de aproximadamente $2 \times 2$ $\mathrm{cm}$, de consistencia elástica, no desplazable e indolora (Fig. 1). La apertura oral, de $30 \mathrm{~mm}$, produce una leve crepitación articular, con laterodesviación al lado izquierdo.La exploración parotídea, del nervio facial, pares craneales, intraoral y cervical no aporta hallazgos.

En las pruebas de imagen, la radiografía panorámica evidenciaba un cóndilo ligeramente irregular, respecto al contralateral (Fig. 2).

La TC mostró una lesión hipodensa precondílea de $18,4 \mathrm{~mm}$ por $31,7 \mathrm{~mm}$. Se extendía medialmente, dirigiéndose hacia la base del ala externa de la apófisis pterigoides y erosionando parcialmente el suelo de la fosa cerebral media (Fig. 3).

La RM demostró una importante distensión anterior de la cápsula articular, que conformaba los márgenes de la tumoración (Fig. 4). En su interior se hallaba una señal hiperintensa compatible con exudado y múltiples señales hipointensas de dimensión variable y densidad similar al menisco o fibrocartílago articular (Fig. 5).

Con el diagnóstico de presunción de tumoración de origen articular, compatible con condromatosis sinovial, se efectuó el abor-



Figura 1. Vista preoperatoria de la paciente. Figure 1. Preoperatory view of the patient.

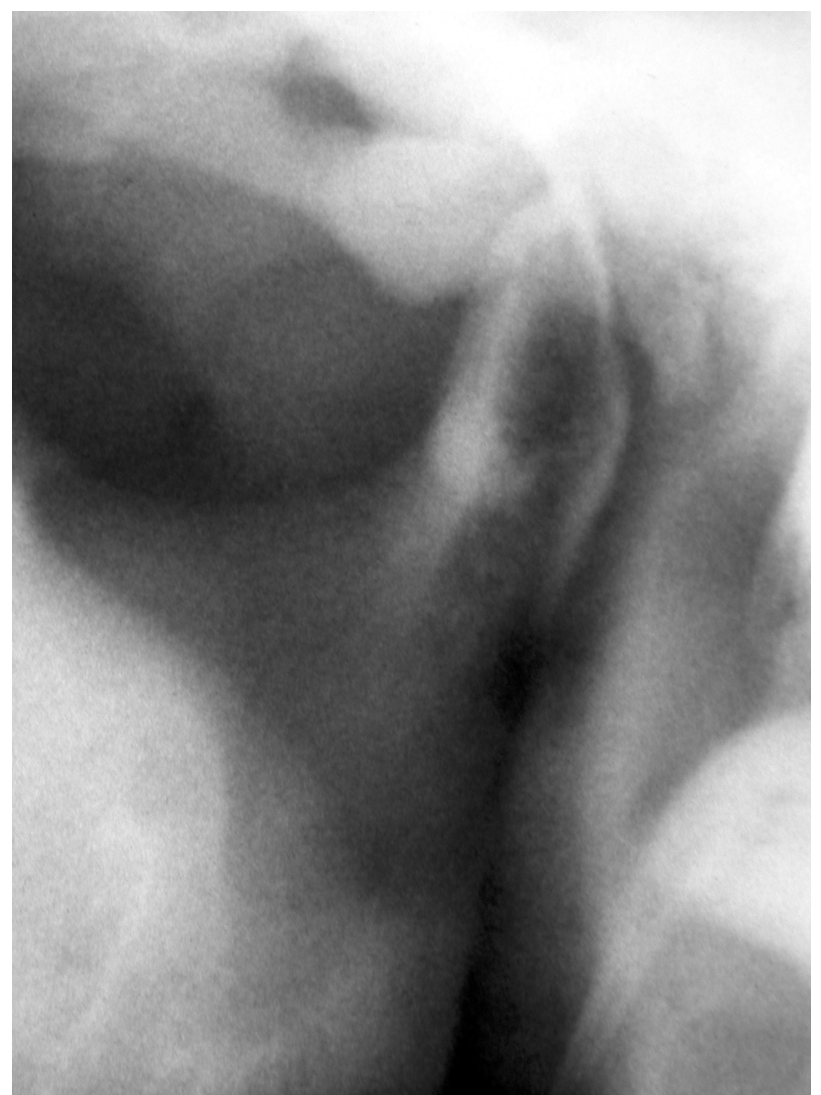

Figura 2. Detalle de la articulación afectada en la OPG. Figure 2. Detail from the paronex of the affected joint.

\section{Introduction}

Synovial chondromatosis (SC) of the temporomandibular joint (TMJ) is a very rare condition. It develops as a result of chondrometaplasia of the subintimal layer of the synovium. Multiple cartilaginous nodules are formed that break off into the joint space. In most cases the process is limited to this space, but on occasions the joint capsule becomes distended, protruding towards the parotid region or skull base. Aggressive behavior has been described with erosion of the temporal bone and intracranial extension.

\section{Case report}

Female, forty-four years old, attended our department as a result of limited oral aperture that was progressive, and a preauricular tumorlike mass on the left side, which had been developing for years. She had no medical history of interest.

The examination revealed a tumor-like mass that measured approximately $2 \times 2$ $\mathrm{cm}$, with an elastic consistency, that was fixed and non-tender (Fig. 1). Oral aperture of $30 \mathrm{~mm}$ produced slight joint crepitation with laterodeviation towards the left. The examination of the parotid, facial and cranial nerves, and the intraoral and cervical examination were unremarkable.

With regard to the imaging studies, the panoramic radiography showed a condyle that was slightly irregular compared with the contralateral side (Fig. 2).

The CT scan showed a precondyloid hypodense lesion, measuring $18.4 \mathrm{~mm}$ by $31.7 \mathrm{~mm}$. It extended medially towards the base of the external wing of the pterygoid process 
daje de la lesión. Tras una incisión preauricular, se expuso la cápsula articular, muy distendida y de aspecto violáceo, hiperémico. Al abrir la cápsula protruyó el tejido sinovial, engrosado, inflamatorio y muy friable. Expuesto el espacio articular, aparecieron múltiples cuerpos libres, más de 40, de aspecto blanquecino, con tamaños y formas irregulares, y consistencia pétrea. Algunos salieron espontáneamente, sobre todo los más pequeños; el resto se extrajeron instrumentalmente (Figs. 6 y 7).

Tras distracción condilar y lavado profuso se comprobó la ausencia de cuerpos libres intraarticulares, procediéndose a la disección de la cápsula distendida en sentido medial. Se resecó el exceso capsular y la membrana sinovial visible, sin cambios metaplásicos macroscópicos. El menisco, moderadamente deformado y luxado anteriormente, se suturó al tejido retrodiscal. La cápsula se cerró, colocándose un drenaje aspirativo previo al cierre de la herida.

El postoperatorio cursó sin incidencias. El examen patológico demostró múltiples nódulos de cartílago hialino, recubiertos por epitelio sinovial (Fig. 8). La membrana sinovial presentaba signos inflamatorios, sin condrometaplasia. La paciente inició fisioterapia precozmente, hallándose seis meses después asintomática, con una apertura oral de 37 $\mathrm{mm}$.

\section{Discusión}

La condromatosis sinovial (CS) suele afectar a grandes articulaciones del esqueleto axial. Es más frecuente en mujeres, y en la articulación derecha. 3,4 Se diagnostica a mayor edad, cuarta y quinta década, que en el resto de localizaciones, ${ }^{3}$ y excepcionalmente es bilateral. ${ }^{1}$ Aunque los macro y microtraumatismos han sido implicados, ${ }^{3}$ su etiología es desconocida.

Se distinguen 2 formas: La CS primaria, una metaplasia condral de restos de tejido mesenquimal a nivel subsinovial. Tiene 3 estadios: ${ }^{2}$ 1-Proceso limitado a la membrana sinovial, formando papilas hiperémicas y edematosas. 2-

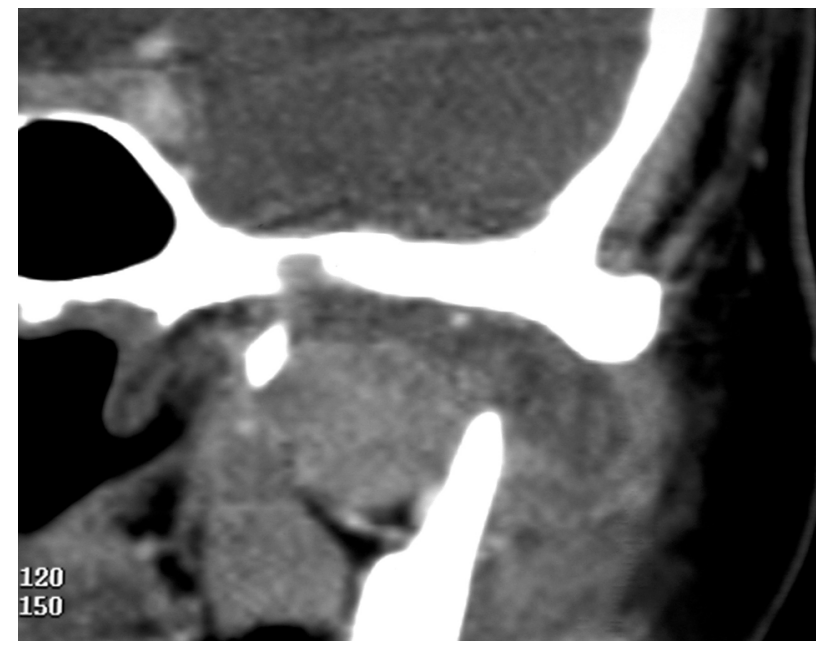

Figura 3. Corte coronal de la TC. Figure 3. CT coronal view.

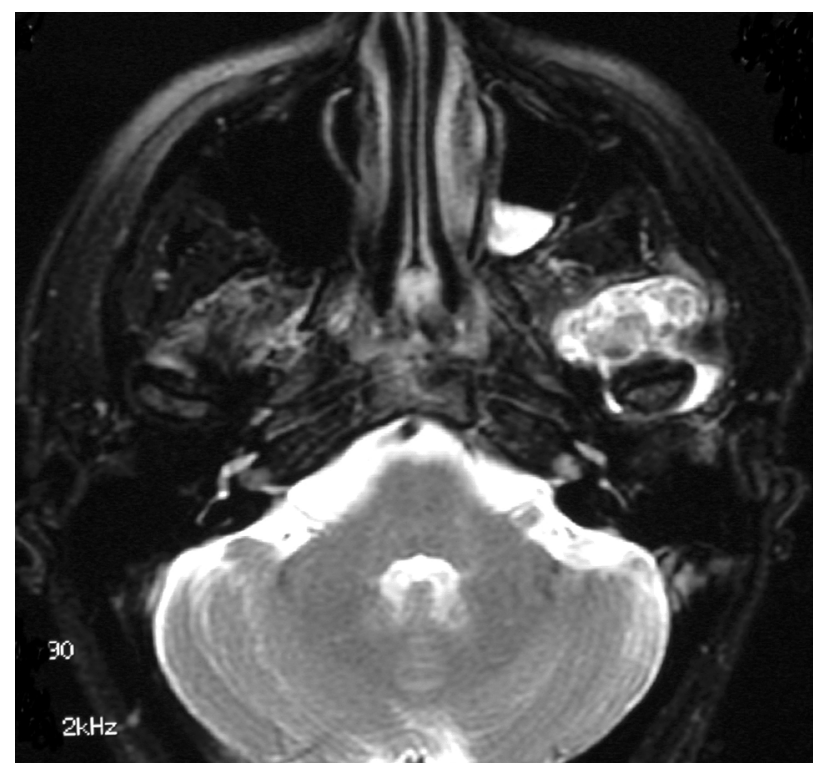

Figura 4. RM potenciada en $T_{2}$ con señal hipertensa. Figure 4. $T_{2}$ of the MR with hypertense signal.

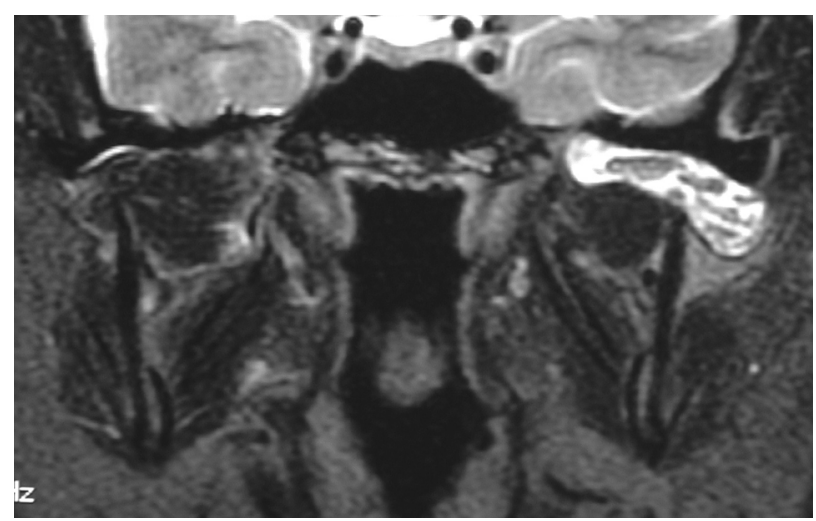

Figura 5. Corte coronal de RM $\left(\mathrm{T}_{2}\right)$ con cuerpos libres intraarticilares. Figure 5. Coronal view of the $M R\left(T_{2}\right)$ with intraarticular loose bodies. and the floor of the middle cranial fossa was partially eroded (Fig. 3).

MRI showed considerable distension of the joint capsule anteriorly, along the margins of the mass (Fig. 4). Its interior was hyperintense and compatible with exudate. There were multiple hypointense signals with variable dimensions, and with a similar density to meniscus or joint fibrocartilage (Fig. 5).

With a presumed diagnosis of a tumor-like mass originating from a joint, compatible with synovial chondromatosis, the lesion was approached by means of a preauricular incision. The joint capsule, which was very distended purplish and hyperemic, was exposed. On opening the capsule, synovial tissue protruded that was thick, inflamed and friable. Once the joint space had been exposed, multiple loose bodies appeared, more than 40, that were whitish and of irregular shapes and sizes and with a stony consistency. Some emerged spontaneously, particularly the smaller ones, and the rest were removed with instruments (Figs. 6 and 7). Following condylar distraction and extensive lavage, no further intra-articular loose bodies were observed, and the stretched capsule was dissected in the median plane. The capsular excess and visible synovial membrane were resected, and no metaplastic changes were observed macroscopically. The meniscus, which was moderately deformed and anteriorly luxated, was sutured to the retrodiscal tissue. The capsule was closed, and aspiration 
Metaplasia subsinovial con presencia de partículas libres intraarticulares, con condrocitos activos. 3-Partículas libres, con membrana sinovial normal.

La CS secundaria, mucho más frecuente, ${ }^{17}$ suele ser debida a cambios artrósicos o traumáticos, con liberación de fragmentos osteocondrales al espacio articular.

Con la evolución de la enfermedad, los nódulos cartilaginosos pueden crecer y calcificarse, la sinovial se engruesa y aparecen cambios degenerativos en las superficies articulares. ${ }^{2}$

Los síntomas más frecuentes son: ${ }^{3}$ dolor, inflamación, limitación del movimiento articular, crepitación, clics. Al ser la clínica inespecífica y benigna, es frecuente el diagnóstico tardío.

El diagnóstico diferencial tendrá en cuenta: procesos musculares; artropatías inflamatorias y traumáticas; disfunción temporomandibular; anquilosis; e infecciones como la tuberculosis. Si la afectación es posterior, puede simular una lesión del oído medio o externo; la extensión anterior y lateral puede sugerir una tumoración parotídea, ${ }^{16}$ habiendo sido confundido histológicamente con un tumor mixto benigno. ${ }^{12}$ En ocasiones se ha descrito la coexistencia de CS con sinovitis villonodular, hiperplasia condilar y otras patologías, ${ }^{3}$ lo que dificulta el diagnóstico.

La radiología convencional es negativa en $24-57 \%$ de los casos. ${ }^{3}$ Sólo si los cuerpos libres están calcificados serán visibles. Los signos indirectos son inespecíficos: erosiones óseas, esclerosis, aumento del espacio articular.

La TC puede definir el tamaño, forma y localización de los cuerpos libres, aunque la prueba de elección es la RM, que permite el diagnóstico diferencial con otros trastornos proliferativos sinoviales, delimita la extensión de la lesión, localiza los condromas y confirma el origen sinovial de la lesión. ${ }^{11,12}$ Es especialmente útil cuando se sospecha extensión intracraneal, para valorar la proximidad y afectación de la duramadre y planificar la cirugía.

Una adecuada valoración mediante TC o RM puede evitar parotidectomías y condilectomías innecesarias. ${ }^{10}$

El mejor procedimiento diagnóstico es el artroscópico. Demostrará la presencia de cuerpos libres intraarticulares de naturaleza condroide, así como posibles áreas metaplásicas sinoviales. ${ }^{5}$ El número de cuerpos libres puede sugerir el diagnóstico: ${ }^{14}$ la mayoría de

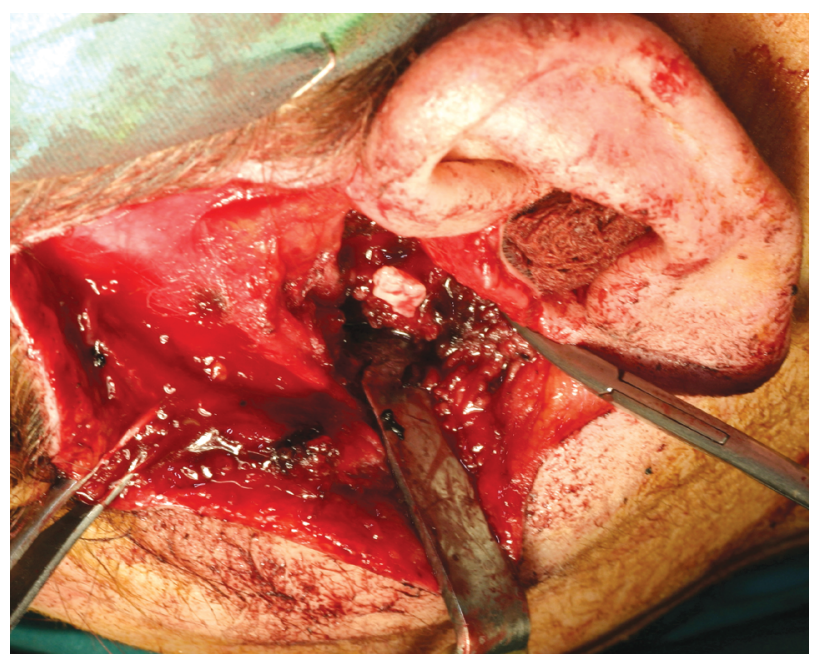

Figura 6. Abordaje de la articulación izquierda.

Figure 6. Approach to the left joint.

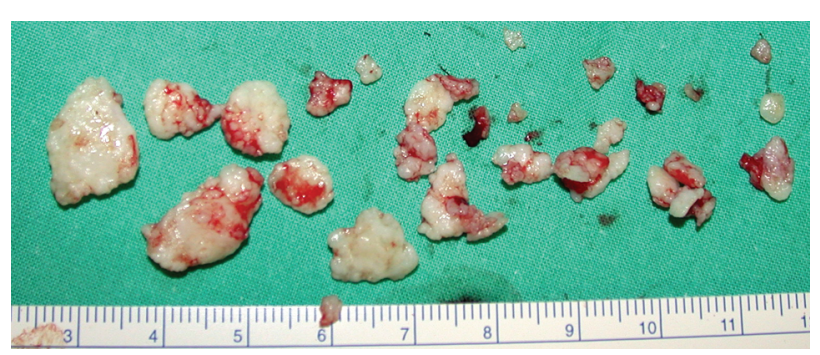

Figura 7.

Figure 7.

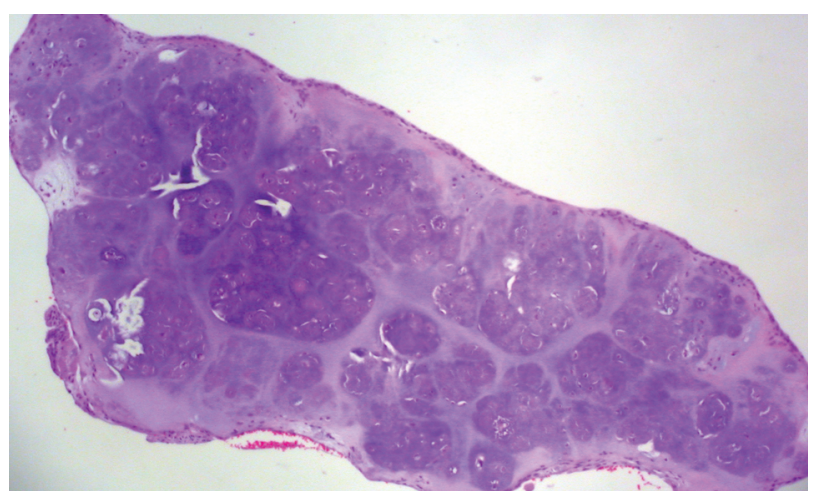

Figura 8. Histología de un nódulo articular (HE) Figure 8. Histology of an intraarticular Body (HE). drainage was placed before closing the wound.

There were no incidents during the postoperative period. The pathological examination showed multiple nodules of hyaline cartilage that were covered by synovial epithelium (Fig. 8). The synovial membrane showed signs of inflammation, but with no chondrometaplasia. The patient started physiotherapy promptly, and six months later she was asymptomatic. Her oral aperture was $37 \mathrm{~mm}$.

\section{Discussion}

Synovial chondromatosis (SC) tends to affect the larger joints of the axial skeleton. It is more common in women, in right-sided joints. ${ }^{3,4}$ It is diagnosed later on in life, during the fourth and fifth decades, than in the remaining locations ${ }^{3}$ and exceptionally it can be bilateral. ${ }^{1}$ While macro- and microtraumatism have been implicated, ${ }^{3}$ its etiology is unknown.

Two types have been identified; primary SC is a chondral metaplasia of mesenchymal tissue remains at a subsynovial level. It has three stages:2 Stage one is a process that is limited to the synovial membrane, and hyperemic and edematous papillae are formed. In stage two, synovial metaplasia occurs. There are intra-articular loose particles and active chondrocytes. Stage three consists of loose particles with normal synovial membrane.

Secondary SC is much more common. ${ }^{17}$ It tends to be due to arthroscopic or traumatic changes as a result of which osteochondral fragments are released into the joint space.

As the disease develops, cartilaginous nodules may appear and become calcified, the synovial tissue thickens and degenerative changes appear in the joint surfaces. ${ }^{2}$ 
pacientes con CS primaria tienen más de 10 cuerpos libres, mientras que el resto de patologías suelen contener menos de 3 .

Microscópicamente, pueden apreciarse islotes de cartílago hialino en el tejido conectivo de la subíntima sinovial, protruyendo en la membrana sinovial o desprendiéndose a la cavidad articular. ${ }^{4}$ Estos nódulos pueden calcificarse y sufrir osificación encondral, de forma parcheada e irregular, habitualmente de la periferia al centro. ${ }^{7}$ Los condrocitos se disponen agrupados de forma irregular por todo el nódulo (Fig. 8), mostrando con frecuencia atipias ${ }^{3}$. Las formas secundarias presentan nódulos de mayor tamaño, con superficie más regular. Su sección suele mostrar una zona central con el fragmento osteoarticular que inició el proceso. Presentan menor celularidad y más uniforme, así como una histología más benigna. Las calcificaciones se disponen en bandas o de forma concéntrica, formando anillos.

El diagnóstico diferencial más importante debe realizarse con el condrosarcoma sinovial, el cual muestra una histología similar, pero la celularidad no se dispone en racimos y asocia signos de infiltración ósea agresiva, con un patrón permeativo. ${ }^{4}$ Se han descrito algunos casos de transformación maligna a condrosarcoma en la ATM. Se debe sospechar ante una CS tratada, con recidivas múltiples y en cortos espacios de tiempo. ${ }^{13}$

El tratamiento se basa en la exploración quirúrgica abierta o artroscópica, con retirada de los cuerpos libres y sinovectomía parcial de las áreas inflamadas y metaplásicas. ${ }^{5}$ La vía artroscópica sería el método de elección si las pruebas de imagen demuestran afectación exclusiva del espacio superior, sin afectación extraarticular y con un tamaño de los nódulos menor de 2-3 mm, retirando los condromas por la cánula de instrumentación y efectuando una abrasión de las áreas de sinovial afectadas. Sin embargo, no permite evacuar cuerpos libres de gran tamaño y la recidiva puede ser más frecuente. $3,7,8$

Ante nódulos extraarticulares en zonas de difícil acceso puede considerarse una actitud conservadora. Si no tienen relación con la sinovial, pueden permanecer asintomáticos y con el mismo tamaño durante años. ${ }^{6}$

Hay pacientes con una historia de larga evolución en los que la CS tiene un comportamiento localmente destructivo, con erosión de la fosa glenoidea o infratemporal y extensión hacia la fosa cerebral media; aunque se mantiene extradural, se han descrito erosiones óseas masivas, con desplazamiento de estructuras y parálisis del nervio facial. $7,9,11,12,15$ En estas situaciones el diagnóstico diferencial debe realizarse con procesos neoplásicos. Se debe asegurar el control local y la exéresis completa que permita su análisis posterior, para descartar malignidad, y evitar el riesgo de degeneración de la lesión residual. ${ }^{11,12}$

Se han descrito recidivas hasta en un $30 \%$ de los casos, posiblemente por resección incompleta de la sinovial metaplásica, no encontrando diferencias algunos autores entre cirugía abierta o artroscópica. 4,14 El examen histopatológico de la membrana sinovial es lo único que puede determinar si la situación ha alcanzado una fase de estabilidad o no, esto no se puede inferir por el aspecto de la articulación o las partículas. ${ }^{7}$

Estudios recientes investigan la posibilidad de que la CS pueda ser secundaria a una proliferación clonal, neoplásica. ${ }^{12}$

Es recomendable mantener un control periódico, indefinido, del paciente.
The most frequent symptoms are: 3 pain, inflammation, limited joint movement, crepitation, clicks. As the clinical symptoms are unspecific and benign, the diagnosis is often delayed.

The differential diagnosis takes into account: muscular processes, inflammatory and traumatic arthropathies, temporomandibular dysfunction, ankylosis and infections such as tuberculosis. If there is posterior involvement, it may appear to be a lesion of the middle or external ear; anterior and lateral extension may be suggestive of a parotid tumor. ${ }^{16} \mathrm{His}$ tologically it has been confused with a benign mixed tumor. ${ }^{12}$ On occasions the coexistence of SC has been described with villonodular synovitis, condylar hyperplasia and other pathologies, ${ }^{3}$ which makes diagnosis difficult.

Conventional radiology is negative in $24-57 \%$ of cases. ${ }^{3}$ Only if the loose bodies are calcified will they be visible. The indirect signs are unspecific: bone erosion, sclerosis, joint space increase.

The CT scan will show the size, form and location of the loose bodies, although the modality of choice is MRI, as a differential diagnosis can be carried out with other synovial proliferative disorders, the size of the lesion is shown, the chondromas are located and the synovial origin of the lesion is confirmed..$^{11,12}$ It is particularly useful when extracranial extension is suspected in order to evaluate the proximity and involvement of the duramater and for planning the surgery.

Adequate evaluation by means of a CAT scan or MRI can avoid unnecessary parotidectomies and condylectomies. ${ }^{10}$

The best diagnostic procedure is the arthroscopy. Intraarticular loose bodies with a chondroid nature will be shown, as well as possible areas of synovial metaplasia. ${ }^{5}$ The number of loose bodies may be suggestive of the diagnosis. ${ }^{14}$ Most patients with primary SC have more than ten loose bodies, while the remaining pathologies have less than three.

Microscopically islands of hyaline cartilage can be appreciated in the connective tissue of the subintimal synovial layer, that protrude into the synovial membrane or that have come away from the joint cavity. ${ }^{4}$ These nodules can become calcified and they may undergo enchondral ossification, in an irregular and patchy manner, normally from the outside towards the center. ${ }^{7}$ The chondrocytes are distributed in groups in an irregular manner throughout the nodule (Fig. 8), and they often show atypical features. ${ }^{3}$ The secondary forms have nodules of a larger size with a more irregular surface. Once sectioned, a central area tends to appear with the osteoarticular fragment that started the process. It is less cellular and more uniform and, histologically, it is more benign. The calcifications are arranged in bands or they may have a concentric shape and form rings.

The most important differential diagnosis should be made with synovial chondrosarcoma. It has a similar histology but it is not made up of cellular clumps. Signs of aggressive bone infiltration can be seen together with a permeative pattern. ${ }^{4}$ some cases of malignant transformation to chondrosarco- 


\section{Bibliografía}

1. Keogh CF, Torreggiani WC, Munk PL. Bilateral synovial chondromatosis of the temporomandibular joint. Clin Radiol 2002;57:862.

2. Milgram WJ. The classification of loose bodies in human joints. Clin Orthop 1997;124:282-91.

3. Petito AR, Bennett J, Assael LA. Synovial chondromatosis of the temporomandibular joint: Varying presentation in 4 cases. Oral Surg Oral Med Oral Pathol Oral Radiol Endod 2000;90:758-64.

4. Jiang W, Mishra S, Francis HW. Quiz case 4. Arch Otolaryngol Head Neck Surg 2000;126:903-8.

5. Holmlund $A B$, Eriksson L, Reinholt FP. Synovial chondromatosis of the temporomandibular joint. Clinical, surgical and histological aspects. Int / Oral MaxiIlofac Surg 2003;32:143-7.

6. Ishii J, Kobayashi J, Amagasa T. Synovial chondromatosis of the temporomandibular joint: long-term postoperative follow-up of the residual calcification. J Med Dent Sci 2003;50:133-7.

7. Lucas JH, Quinn P, Foote J. Recurrent synovial chondromatosis treated with menisectomy and synovectomy. Oral Surg Oral Med Oral Pathol Oral Radiol Endod 1997;84:253-8.

8. Mendoca-Caridad JJ, Schwartz HC. Synovial chondromatosis of the temporomandibular joint: Arthroscopic diagnosis and treatment of a case. J Oral MaxiIlofac Surg 1994;52:624-5.

9. Yu Q, Yang J, Wang P. CT features of synovial chondromatosis in the temporomandibular joint. Oral Surg Oral Med Oral Pathol Oral Radiol Endod 2004;97:5248.

10. Nitzan DW, Marmary Y, Fields SI. The diagnostic value of computed tomography in temporomandibular joint synovial chondromatosis. Comput Med Imaging Graph 1991;15:53-6.

11. Wong WC, Cheng PW, Chan FL. MRI appearance of synovial chondromatosis of the temporomandibular joint. Clin Radiol 2001;56:773-82.

12. Nussenbaum B, Roland PS, Gilcrease MZ. Extra-articular synovial chondromatosis of the temporomandibular joint. Pitfalls in diagnosis. Arch Otolaryngol Head Neck Surg 1999;125:1394-7.

13. Sesenna E, Tullio A, Ferrari S. Condrosarcoma of the temporomandibular joint. J Oral Maxillofac Surg 1997;55:1348-52.

14. Yildiz ST, Demir A, Kaya A. Synovial chondromatosis of the temporomandibular joint extending to temporalis, masticator end parotid spaces. / Comput Assist Tomogr 2001;25:126-9.

15. Sun S, Helmy E, Bays R. Synovial chondromatosis with intracranial extension. A case report. Oral Surg Oral Med Oral Pathol 1990;70:5-9.

16. Hamilton JS, Jones-Quaidoo S, Osborne RF. Synovial chondromatosis of the temporomandibular joint space. Ear Nose Throat J 2005;84:342-3.

17. Ardekian L, Faquin W, Troulis MJ, Kaban LB, August M. Synovial chondromatosis of the temporomandibular joint: report and analysis of eleven cases. J Oral Maxillofac Surg 2005;63:941-7. ma have been described in the TMJ. This should be suspected following SC treatment when there are multiple relapses in a short space of time. ${ }^{13}$

Treatment is based on surgical examination, either open or arthroscopic, and the removal of the loose bodies together with a partial synovectomy of the inflamed and metaplastic areas. 5 The arthroscopic approach is the method of choice if the imaging studies show that only the upper space has been affected, if there is no extra-articular involvement, and if the size of the nodules is less than 2-3 mm. The chondromas can be removed through the instrument cannula and the affected synovial areas should be abraded. However, large sized loose bodies cannot be removed in this way, and there may be more frequent cases of relapse. $3,7,8$

If there are extra-articular nodules in areas that are difficult to access, a conservative view can be taken. If there is no synovial involvement, they can remain asymptomatic and not change in size for years. ${ }^{6}$

There are patients with a long history of SC that is locally destructive, with erosion of the glenoid or infratemporal fossae and with extension towards the middle cranial fossa. Although it may remain extradural, massive bone erosion has been described, with displacement of structures and paralysis of the facial nerve. $7,9,11,12,15$ In this situation the differential diagnosis should be carried out with neoplastic processes. Local control should be ensured, together with complete exeresis enabling posterior analysis so as to rule out malignancy, and in order to avoid the risk of degeneration of the residual lesion. ${ }^{11,12}$

Relapses have been described in up to $30 \%$ of cases, possibly as a result of incomplete resection of the metaplastic synovium, while some authors have not found any differences between open or arthroscopic surgery.4,14 Only will the histopathologic examination of the synovial membrane determine if the condition has stabilized or not, as this cannot be assumed from the appearance of the joint or the particles. ${ }^{7}$

The latest studies are investigating the possibility that SC may be secondary to a neoplastic clonal proliferation. ${ }^{12}$ A periodic, indefinite following of the patient is advised. 